\title{
Corporate Failure and the Role of Governance: The Parmalat Scandal
}

\author{
Emmanuel O. Ogutu
}

\author{
MBA graduate, Utica College, Utica, New York
}

\begin{abstract}
Being touted as the biggest scandal in terms of value, the Parmalat scandal offers a good opportunity to investigate and analyze the role of corporate governance in the failure of corporations particularly in the United States, Europe, as well as in emerging economies. This paper examines Parmalat's history and describes the circumstances that led to the massive accounting fraud and collapse of Europe's and indeed one of the world's leading dairy producers. This paper highlights and points out how weak and ineffective corporate governance structure and process heavily contributed to other problems within Parmalat and eventually led to its demise in the fall of 2003. This paper incorporates various studies conducted in the past on corporate governance and corporate failure. Organizations with strong and effective corporate governance structure and processes demonstrate better performance in all areas than those with weak corporate governance processes.
\end{abstract}

\section{Indexing terms/Keywords}

corporate governance, corporate failure, fraud, complicity, outside auditors, Parmalat, board of directors, top management, enforcement, regulations, compliance, accounting, performance, measures, analysts, monitoring

\section{Academic Discipline And Sub-Disciplines}

Strategic Management and Leadership

\section{TYPE (METHOD/APPROACH)}

Examination and analysis of a past event in an effort to inform present and future activities.

\section{INTRODUCTION}

The Parmalat scandal remains on the biggest corporate scandals to have happened over the last 15 years. Indeed, no other than the United States Security Exchange Commission (SEC) described the scandal as "one of the largest and most brazen corporate financial frauds in history (SEC, 2003)." Jones (2011) also stated that Parmalat was a typical example of accounting fraud that had taken place in the modern day Italy, perpetuated by a weak corporate governance structure and process, failure to exercise due professional care by the auditors, as well as greed y the founder and top management team. The governance structure at Parmalat was so weak, with a controlling shareholder who simply took advantage of this weakness and used it to further his own personal benefit instead of furthering Parmalat's interests (Ferrarini \& Giudici, 2005). With the collapse of Parmalat which caused ripples in the financial circles across the world, and in Italy in particular, the role of corporate governance has been constantly put under scrutiny in Italy as well as across the globe. For instance, in order to respond to critics and analysts, ensure Europe's corporate requirements are adhered to and investor confidence is restored, Italy passed legislation that is geared towards reforming the corporate environment, with regulatory agencies gaining more enforcement powers including powers to carry out investigation and to sanction rogue corporations (PR Newswire, 2006). This is aimed to ensure corporations play by the required laws, prevent a scandal such as Parmalat's and enhance deterrence. Jones (2011) further points out that what happened at Parmalat was deliberate and blatant misstatement of information with the intention to deceive. This was done under the Chair and CEO in collaboration with the CFO. No organization whatever its size, or the industry in which it operates or how qualified its management is, can survive without three very strong pillars: (1) a strong and effective governance structure and process; (2) a robust and sustained ethical climate; and (3) effective internal control system built upon a sound control environment. It is almost not possible to have a robust ethical climate and an effective internal control system without an effective, well thought out and strong governance structure and process that is functional at all levels of the organization. At the core of this is tone at the top, which is basically the attitude and actions of the management and those charged with governance within an organization towards such things as ethics and controls and how they view this in their daily activities. When the governance process within a corporation is weak, compromised or abused, then the organization however strong it is, remains exposed to management excesses, poor oversight and in extreme cases such as Parmalat's, collapse. Over the last 20 years for instance, cases of corporate failure have been devastating world over with many of these pointing various reasons ranging from rogue management, accounting fraud, weak internal control system, complicity by auditors, lack of effective oversight by regulators, among others, which all point to problems in governance structure and process. Arjoon (2005) supports this assertion by alluding that many of the examples of corporate failure have been attributed to various reasons including questionable accounting practices, abuse of power, insider trading, fraud, corruption and bribery, improper investment practices, pursuit of short term profits at the expense of protecting shareholder interest, weak control environment as well as management incompetence. All these rest on the pillar of governance and more often, a weakness in governance is normally the cause of these. Indeed, corporate failures have led to loss of investment and many have suffered with some losing their lives due to deterioration of health as a result of depression. Jobs have been lost and lives shattered by the greed exhibited by rogue corporate executives such as was the case in the likes of Enron, WorldCom, in the US, Northern Rock and Royal Bank of Scotland in the United Kingdom, other corporations in India, China, and SubSaharan Africa as well as Parmalat which is the focus of this paper, among others. In the case of Parmalat, Calisto Tanzi, 

the founder and CEO of Parmalat had sustained greed and unethical behavior that included diverting Parmalat's funds to a corporation associated with his daughter, Francesca Tanzi. "New detention in Parmalat probe" (2004) reported that Tanzi siphoned about $€ 500$ million to Permatour, the company that his daughter worked for and managed. Scott and Davis (2007), point out that, key officials of organizations should be appointed in a way that ensures they are free from being influenced by social affiliations. They further argue that kinship and family roles may breed conflict, erode focused decision making and impact behavior patterns to the detriment of the organization. This is exactly demonstrated in the actions of Tanzi and his family. In this paper, I will discuss in details how corporate governance plays a role in the performance of organizations and how corporate failures in the past and recent times have been perpetuated by weak governance structures and processes mixed with greed and unethical practices. I will highlight how blatant disregard of sound corporate governance processes contributed to the collapse of Parmalat and the steps corporations need to take to avoid a similar downfall and enhance their governance processes by increasing accountability among its executives, sustaining trust, insisting on robust ethical climate and culture as well as strengthening their control environment and compliance mechanisms. I will also briefly trace Parmalat's history from its upsurge in the mid to late $20^{\text {th }}$ Century to its collapse in December 2003. I will further describe the circumstances that led to the collapse and the role of key players. I will demonstrate how the collapse of Parmalat was as a result of a weak, compromised and ineffective governance process sustained by a rogue founder with no conscience for ethics and sound principles of good and effective governance. I will also discuss briefly about corporate governance in emerging economies and the corporate governance lessons that players in the emerging economies can learn from the Parmalat scandal. This will lead to a final section where I will provide recommendations that corporations in the United States and globally should put in place to ensure strong governance structures and processes that will help set a foundation for success in every area of their operations and reduce exposure to the consequence suffered by other collapsed corporations, with specific focus on Parmalat.

\section{PRINCIPLES OF CORPORATE GOVERNANCE}

O'Shea (2005) observes that there are six globally acknowledged principles of effective governance. These principles are; (1) a balance of functions and responsibilities of executive and non-executive directors; (2) a clear division of responsibilities between the chair of the board and the chief executive officer (CEO); (3) provision of timely, accurate and complete information to the board; (4) formal, transparent and clear procedures for the appointment of new directors and accountability to shareholders; (5) balanced and understandable financial reporting structure and procedures; and (6) maintenance of a sound, robust and effective internal control system. These principles are consistent with the Organization for Economic Co-operation and Development (OECD)'s recently updated principles for corporate governance by the G-20 and OECD member countries. OECD's principles include; (1) ensuring an effective framework for corporate governance; (2) respecting and affirming the rights and equitable treatment of shareholders and key ownership functions; (3) developing sound economic policies with a particular focus on institutional investors; (4) encouraging co-operation between a corporation and its stakeholders; (5) sustaining a culture of disclosure and transparency by ensuring timeliness, accuracy and completeness of information provided to all stakeholders; and (6) defining and clearly providing guidance to the board on its responsibility and oversight over management of key activities of the corporation (OECD, 2015). Regardless of the size and type of organization and industry, the principles of governance apply to all organizations and are also critical to sustaining the integrity of an organization and its officials. Parmalat's management failed to articulate these principles and incorporate them into its operating environment, setting the stage for what became the biggest corporate failure in modern times.

\section{HISTORY OF PARMALAT AND ITS COLLAPSE}

Calisto Tanzi entered the milk Market in the nineteen sixties, capitalizing on the continuous packaging process developed by Tetra Pak and thus Parmalat began its expansion into the dairy sector. Parmalat brand became popular in the seventies because of the fact that it sponsored sports, thus enabling it to venture into the Latin American markets (Ferrarini and Giudici, 2005). Segato (2006) points out that in 1997 Parmalat made the decision to become a "global player" and began a major campaign of international acquisitions, in the Northern and Latin American markets mainly financed through debt. Within a very short time, Parmalat had become the third largest manufacturer of cookies in the United States alone. Ferrarini and Giudici (2005) further point out that through the influence of politicians, Mr. Tanzi ventured into Media and started Odeon TV which went through financial turmoil eventually becoming bankrupt in 1989. This forced Mr. Tanzi to pay huge debts on behalf of Odeon TV which he had personally guaranteed. Interestingly, it was eventually discovered during the criminal investigations following Parmalat's collapse, that these debts were actually settled by funds provided by Parmalat. Through a complicated financial transaction, the Tanzi family's company that was holding Parmalat's shares, Coloniale, used its controlling strength as consideration that did not involve cash, to raise capital of Finanziaria Centro Nord, a public company that later became Parmalat Finanziaria (Ferrarini and Giudici, 2005). This resulted in a complex structure for the group that was difficult to understand. Melis (2005) provides an account of the complexity of Parmalat's group structure indicating that, despite laws governing disclosure, the group's structure was difficult to trace especially at a global level. In order to sustain a strong governance process, a corporation's ownership structure should be easy to understand and to trace otherwise, a strong shareholder could exploit this to perpetuate fraud, conceal illegalities and oppress minority shareholders. See Figure 1 for a simplified ownership structure of the Parmalat Group. Melis (2005) stresses that the main corporate governance problem in Italy was weak and incompetent managers; strong block holders; and unprotected minority shareholders. Parmalat's case demonstrates a situation where Tanzi exploited the week and ineffective governance structure and processes to siphon corporate funds and channel themto himself and his kin in a scandal that is billed to have been one of the biggest scandals world over. 


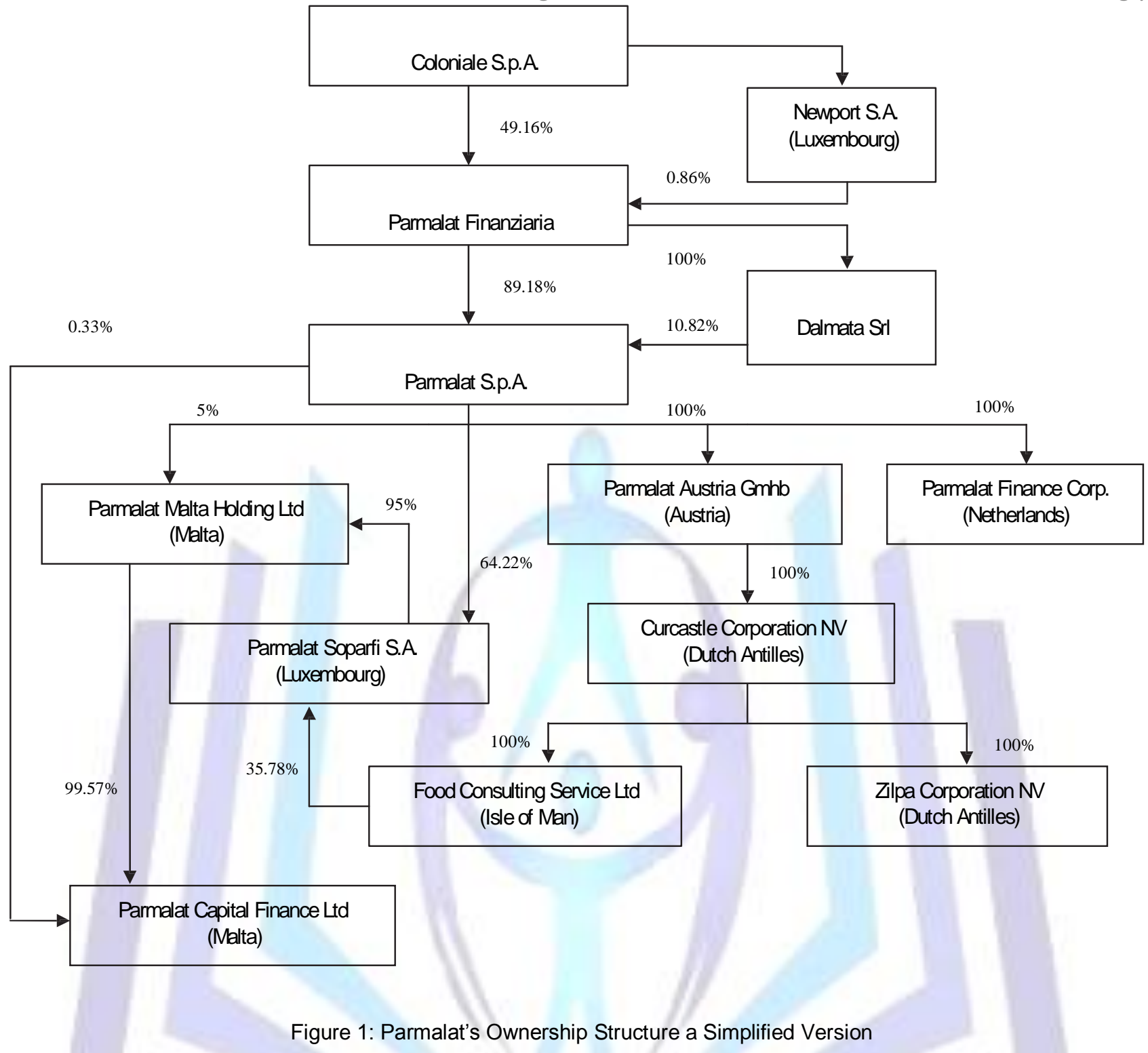

Parmalat continued its expansion spree largely financed by debt and in the 1990s diversified into football, acquiring Parma Calcio (Parma's Soccer club) in Italy, Palmerias, a club in Brazil and Audax Italiano, a club in Chile. Mr. Tanzi's son, Stefano, became the President of Parma in 1996. Mr. Tanzi also ventured into tourism industry and through numerous acquisitions comprised of complex transactions, HIT, the tourism corporation of the Tanzi family hit turnover of Euros 550 million, generating massive losses and huge debts. Tanzi's daughter, Stefania, was in charge of the tourism business. At the end of 1990s Parmalat was still on an expansion spree, buying approximately two dozen companies within two years (1998 to 2000) (Ferrarini and Giudici, 2005). This trend continued into the new millennium with the Parmalat group sustaining a strategy of holding huge cash reserves to be used in mergers and acquisitions and at the same time financing its cash needs through bonds, with little accountability to stakeholders. In reviewing the history of Parmalat and the activities of Calisto Tanzi and his family, it is clear that Tanzi had little regard for corporate governance and his actions led to erosion of governance principles and eventually collapse of Parmalat.

Ferrarini and Giudici (2005), lay out the circumstances surrounding Parmalat's collapse in a very clear way. They indicate that Parmalat's financial statements were showing high levels of cash and debt, with the management led by Tanzi being murky and arrogant towards analysts, investors and other stakeholders just as was the situation with Enron. In October 2002 Parmalat group launched a bond of $€ 150$ million with UBM and Banca Akros acting as underwriters and issued another bond worth $€ 200$ million with Morgan Stanley acting as the sole underwriter. Analysts became wary of Parmalat's borrowing and argued that the debt financing posed a higher risk particularly with the unstable environment in the South America market and suggested that Parmalat's management should accurately and competently assess this, in addition to having no intention to use its $€ 3.3$ billion cash quantity. However, Parmalat's management was not approachable and analysts' reports showed that the group's management's arrogance had become a common issue (Ferrarini and Giudici, 2005). 

"How Parmalat went sour" (2004) reported that Parmalat defaulted on a $\$ 185$ million bond payment in mid-November 2002. This prompted auditors and banks to scrutinize the group's financial statements. This scrutiny revealed that some $38 \%$ of Parmalat's assets were supposedly held in a $\$ 4.9$ billion Bank of America account of a Parmalat subsidiary in the Cayman Islands. But on Dec. 19, 2002, Bank of America reported that no such account existed. In the ensuing investigation, Italian prosecutors said they had discovered that management simply invented assets to offset as much as $\$ 16.2$ billion in liabilities and falsified accounts over a 15 -year period, forcing the $\$ 9.2$ billion company into bankruptcy on Dec. 27. Trading in Parmalat shares was suspended the same day. Auditors first inquired about the Cayman Islands account in December, 2002, and received a letter on Bank of America stationery in March, 2003, confirming the existence of the account. The letter was apparently a forgery, concocted by someone in Parmalat's Collecchio headquarters. The very size of the alleged account should have raised a red flag, notes the CEO of one of Italy's largest banks: "Even a $\$ 1$ million bank account is cross-verified by our auditors." Investigators also believe that in 2003 Parmalat did not buy back $\$ 3.6$ billion in outstanding bonds, although it claimed to have done so.

In April 2003 Mr. Tanzi had announced the resignation of Parmalat's group CFO, Mr. Tonna who was replaced by Mr. Ferraris. Additionally, Parmalat's management's arrogance and lack of corporation was reported to Consob, the Italian regulator who directed, Parmalat to be more cooperative. The auditors informed stakeholders that they could not give an opinion on Parmalat's financial statements as a result of complex financial transactions that were not adequately supported or substantiated prompting Consob to issue a letter to Parmalat management asking for more information on these transactions (Ferrarini and Giudici, 2005). As the financial turmoil continued to unfold, Parmalat declared its inability to repay one of the bonds that was maturing on December 8,2003 , forcing the bond to be downgraded to junk. Desperate to sell the company to American investors, Mr. Tanzi confessed in private that the company's records were falsified leading to collapse of its share price and the declaration of insolvency on December 27 as reported by Bloomberg news in the article "How Parmalat Went Sour." As things continued to unfold, Parmalat's management completed the destruction of documentation and hardware that contained evidence of fraud (Ferrarini and Giudici, 2005). Criminal investigations were commenced leading to Mr. Tanzi's conviction and jailing, commencement of insolvency procedures and appointment of Mr. Enrico Bondi as Extraordinary Commissioner.

As Melis (2005) points out, Parmalat's collapse revealed features that are common to corporations that have failed before, such as, fraudulent financial accounting and reporting process, poor performance, political influence, greed, dominant shareholder, complex structures and mysterious operational processes. Key to these was Parmalat's governance structures which was ineffective and grossly weakened by lack of accountability by the CEO and his management, in addition to governance procedures that were not properly designed or implemented. Melis further articulates additional serious failures in corporate governance process that resulted into Parmalat's crisis. These are described briefly in the sections below.

\section{a) Lack of Independence of Non-executive directors}

Clearly, there was a lack of independence on the non-executive directors. As Melis (2005) points out, at least one of the members of the board of Parmalat had worked as a Senior Manager with the group since 1963. This shows that this member could easily be influenced to take biased decisions. Ferrarini and Giudici (2005) highlight that in its first accounting report dated 2001, Parmalat declared that four out of its thirteen directors were independent, yet never provided names of who these directors were. In its 2003 report, Parmalat's eight out of thirteen directors were executive and they included Calisto Tanzi (Chair and CEO); Tanzi's son Stefano; Tanzi's brother Giovanni; nephew Paola Visconti; Parmalat's CFO Fausto Tonna and the senior managers Luciano Del Soldato, Alberto Ferraris and Franseco Giuffredi. Board Committees were also composed of members of executive management. This demonstrates that the corporation's governance structure was a mockery of an effective and strong governance process and largely unethical.

\section{b) Chair and CEO positions and roles were not separated.}

The positions of the Board Chair and the CEO at Parmalat were not separated. Tanzi held both positions. Proponents of CEO and Chair independence base their view on the need to maintain a strong governance structure that ensures effective checks and balances that the board, and particularly the board's Chair, is supposed to impose on management led by the CEO. Principally, a firm's board and Chair of the board serves to hire, fire, evaluate and compensate management (including the CEO) based on performance. Clearly then, these proponents argue, it is difficult to effectively execute the roles of both Chair and CEO under one person as has been demonstrated by the case of Parmalat. A single CEO and Chair cannot perform these tasks apart from his or her personal interests, making it more difficult for the board to perform its critical functions, if and when the CEO is its Chair. Accordingly, separation of the Chair and CEO roles, can lead to better management and oversight because an independent Chair is able to ensure that the board is fully engaged with strategy and to evaluate how well that strategy is being implemented by management led by the CEO. Importantly, appointment of an independent Chair can also signal to all stakeholders that the CEO is accountable to a unified board with a visible leader (Bader, 2013).

\section{c) Disregard of compliance with Italy's corporate governance code}

Solomon (2007) argues that according to Italy's law, where a group of shareholders controls a company, it becomes extremely important that some of the directors be independent of the controlling shareholders. Parmalat did not adhere to this critical corporate governance piece of legislation and no explanation was given for its failure to comply with this legislation. At the core of a strong governance system is an effective compliance process that ensures a corporation 

complies with the relevant rules and regulations in order to promote good governance, accountability and maintain good citizenship status in the environment in which it operates.

\section{d) Failure to implement and adequate and effective monitoring system}

Parmalat's management failed to implement an effective monitoring system. Solomon (2007) argues that this failure by Parmalat to establish a careful, proper and effective checking and monitoring structures within the groups governance framework laid it bare to abuse of power, greed and fraudulent activity. Ferrarini and Giudici (2005) were scathing in their attack on the monitoring structures at Parmalat and laid the blame on the auditors, insisting that Parmalat's successive auditors, Grant Thornton International and Deloitte Touche Tohmatsu, failed to detect fraudulent activity at Parmalat and that Grant Thornton's Italian partners may have been involved in the fraud. They further point out that some high ranking international banks failed to conduct due diligence and warn stakeholders and the market of Parmalat's financial distress. The auditors particularly overlooked the glaring governance deficiencies in Parmalat group. Not only did Parmalat execute a scheme of fraudulently overstating its assets while understating its liabilities through a scheme that involved activities such as recording non-existent repurchase of bonds, mischaracterizing of debts or simple failure to record debts. The entire monitoring system was rotten to the core and Parmalat's auditors and legal advisors literally helped Parmalat's management to sustain this fraud (Ferrarini and Giudici).

\section{CORPORATE GOVERNANCE IN EMERGING ECONOMIES}

In discussing the Parmalat's scandal, it becomes necessary and important to discuss and evaluate the subject of corporate governance in emerging economies. Emerging markets play an increasingly critical role in the world economy, given their high economic growth prospects and their improving physical and legal infrastructures. Combined, these countries account for nearly 40 percent of global gross domestic product, according to the International Monetary Fund. For some investors, emerging markets provide an excellent and lucrative opportunity, but they also involve many sided risks at both the country and corporation levels. These risks require investors to have a much better understanding of the corporation-level governance factors in different sectors (Dallas, 2011). Several studies focusing on emerging economies have analyzed the impact of implementing corporate governance principles on the performance of an organization. In 2001, Credit Lyonnais Securities Asia (CLSA) developed a series of corporate governance rankings for 495 corporations from 25 emerging countries. The report highlighted the fact that organizations that were rated high on the governance index have better operating performance and higher stock returns. Klapper \& Love (2004, pp. 287-322) used the governance rankings produced by CLSA to investigate the relationship between corporate governance and organization performance by employing multivariate regression. Their tests showed that better corporate governance is highly connected with better operating performance and high market valuation. The two researchers further pointed out that wellgoverned firms benefit more in environments where there is bad corporate governance and that by establishing good corporate governance practices, organizations can partially compensate for laws that are not working effectively and also enhance enforcement (Feleagă, Feleagă, Dragomir and Bigioi, 2011).

Dallas (2011) points out that there are several factors that have proven to be essentially critical in shaping organizations' governance principles and choices in the emerging economies and markets. Some of these factors include; (1) the quality of governance in the public sector determines the level of law enforcement which, in turn, affects the extent of bribery and corruption; (2) In countries where government is heavily involved in corporate ownership and control, the quality and competency of government officials and regulators heavily influences corporate behavior; (3) Financial market development is often negatively impacted by weak legal foundations, unethical practices and insider deals. For instance, Chase Bank in Kenya was recently placed under statutory management due to mismanagement. One of the governance problems that was unearthed was of one of the board members had loaned himself $\$ 79$ million which is against the law and Central Bank of Kenya regulations (Irungu, 2016); (4) Ownership structures help determine the nature and difference between the board and management and performance. In many emerging economies, controlling shareholders are mostly family members who also occupy top management positions and succession planning is often implemented with a focus on family members and not on professionalism (Dallas, 2011). This resonates with the natural systems view of organizations whereby, though formal structures exist, they are supplemented, eroded, distorted and changed by the appearance of informal structures (Scott and Davis, 2007). Scott and David further point out that, informal structures are grounded upon personal traits and relations of the specific participants. Villalonga and Amit (2004) highlight that corporations controlled by family members show specific weaknesses when family members are involved in, or are members of the top management. A look at Parmalat shows that the management led by Mr. Tanzi used informal structures to run the organization where the Tanzi-family members were also members of Senior Management of the group. This may have led to the erosion of formal structure where clear reports structures are established and gave way to exploitation of the weakness brought about by the informal structure, eventually negatively impacting Parmalat's corporate governance process. It is important to note that Weak and ineffective boards, that is full of family members, such as the Tanzi family in Parmalat is a big risk to effective governance. As a result, they fail to provide effective oversight to management and also to controlling shareholders and are at the mercy of these controlling shareholders. This results into poorly thought out strategic decision making process or as in the case of Parmalat, the controlling shareholders pursue their own agenda at the expense of the corporation's objectives and thus suppress the interest of minority shareholders. Additionally, weak management is entrenched in the corporation because managerial positions are preserved for family members making it difficult to attract professional and competent talent. These weaknesses are mirrored in the Parmalat Scandal so clearly and are detrimental to governance process and erodes good governance process (Dallas, 2011). 


\section{RECOMMENDATION MEASURES TO ADDRESS GOVERNANCE PROBLEMS IN CORPORATIONS}

Corporate governance is the yardstick by which an organization's financial, operational and compliance well-being can be measured. It is not some form of high level concept reserved for corporation's boardrooms alone. As Edwards (2003) points out, the confidence of the mass public on a corporation is directly proportional to the effectiveness of its governance process. He further highlights that the run-away compensation levels of some CEOs, particularly those whose corporations have been performing poorly both operationally and in the stock market is just one of the aspects of governance that has increased public distrust in these corporations. Even though there was no information readily available regarding compensation of Parmalat's Executives, in the U.S., it is clear that CEOs compensation has continued to generate public debate in the wake of corporate failures that have happened in the last one and a half decades. For instance, Jeffrey Barbakow, CEO of Tenet Healthcare made $\$ 190$ million for the fiscal year ending June 2002, at a time when his company's income was being generated by a huge Medicare fraud perpetrated by Tenet Healthcare. This is just one of the many examples of corporate governance related problems facing organizations today.

Complicity by the gatekeepers is another common corporate governance challenge faced by corporations, and results in shareholders and other investors suffering huge losses. For instance, Parmalat's successive auditors, Grant Thornton and Deloitte and Touche have been accused of knowingly clearing Parmalat's financial records when in fact they knew things were not right at Parmalat. According Italian regulations, corporations must change their outside auditors every nine years. In 1999, Parmalat changed its auditor from Grant Thornton to Deloitte and Touche. Grant Thornton convinced Parmalat to have its subsidiaries remain under it while the parent company be transferred to Deloitte and Touche for audit purposes. This way, Parmalat continued to use the subsidiaries to generate illicit payments to the parent company, whereby the executives at the subsidiaries would create debts owed to Parmalat by the subsidiaries and then Grant Thornton auditors would certify these and present them to Deloitte auditors who would just rubber-stamp them. Media was awash with reports that Grant Thornton accountants were aware of these shell games and shell companies, perpetuated by Parmalat but never raised an issue thus lending credence to the fact that they were an accomplice to Parmalat executives in perpetuating and sustaining these fraudulent activities (Sverige, 2004).

To address the corporate governance challenges faced by corporations in light of the several corporate failures generally and Parmalat in particular, I highlight a number of initiatives and steps that can be taken by corporations and their related stakeholders to improve corporate governance processes, enhance corporate discipline and prevent failure that have impacted the likes of Parmalat, Enron, WorldCom among others. These are discussed in the below sections.

\section{a) Strengthening independent boards}

Board Independence is a critical component that enhances the effectiveness of corporate governance in an organization. Of particular importance, is ensuring that there is a balance between executive and non-executive management such that no single person can dominate board decisions and also accountability of management is sustained. The role of board Chair and CEO should as much as possible, be performed by different individuals and in the case where this is performed by the same individual, the control environment should be very strong and monitoring by regulators, auditors and other reviewers should be enhanced to ensure the Chair/CEO runs the board and the executive in a transparent and ethical manner. Additionally, the board should form an Audit Committee to help the board fulfill its financial reporting responsibilities.

\section{b) Sustaining enforcement through regulation and legislation}

There should be a mechanism by which enforcement is swiftly deployed when there is weak or diminished corporate governance process. Ensuring that regulators take action against violators of effective governance process and that the law swiftly takes its course. The Sarbanes-Oxley laws is one such regulation that has helped in ensuring public companies in the united states are managed effectively and ethically and that corporate governance practices are sustained by corporations' management as well as those charged with governance. Italy has developed corporate governance regulations which Parmalat was required to adhere to. However, as pointed out elsewhere in this paper, Parmalat's management failed to comply with it and no reason was given, and there was no evidence of enforcement by Italy's government policy or regulators such as Consob. Enforcement and compliance should be embedded in an organization's operation to ensure that corporate governance rules, regulations and practices are adhered to by management.

\section{c) Enhance monitoring and compliance}

The role of outside auditors should continue to be strengthened, broadened and governed by enforcement mechanisms. Sarbanes Oxley Act of 2002, limited the assurance roles that can be performed by outside auditors after the Enron and Arthur Andersen collapse. For Parmalat, the auditors, Grant Thornton and Deloitte, failed to exercise due professional care thus leading to approval of fictitious financial statements. As watchdogs particularly for the shareholders, auditors play an important role in enhancing corporate governance by ensuring that a corporation's internal control and financial reporting process are adequate, effective and free from material misstatements. Additionally, ensuring compliance with relevant rules and regulations should form the core of implementing a strong governance process. The board should hold management accountable for compliance with relevant rules and regulations. 


\section{d)Code of Ethics}

Implementation of a code of ethics is critical in strengthening corporate governance process. Feleagă et al., (2011) point out that, in Europe $73 \%$ of companies have such as code. Arrigo (2006) also asserts that the code of ethics is indeed a powerful tool of corporate governance as it highlights corporate responsibilities towards stakeholders and compels members of the top management to comply with the relevant guidelines required of them when exercising their authority, both inside and outside the organization. Arrigo continues to point out that the code of ethics is one of the tools by which an organization can show its commitment to responsible, sustainable and respectable behavior by disseminating information about its own corporate governance, and meeting the stakeholders' growing need for information. Additionally, the code of ethics clarifies to stakeholders the criteria that guides decision making process, as well as being a governance tool, it represents the company's constitutional charter, defining the responsibilities of each member of the organization.

\section{CONCLUSION}

From the review and detailed analysis of the Parmalat scandal, it is important to conclude that a weak corporate governance process within Parmalat, aided by the failure of government to enforce regulations, was a major reason that led to the collapse of Parmalat. This study finds that a weak corporate governance structure has a strong link to corporate failure and that it also impacts on performance of the organizations. Further study should be carried out to determine to what extent corporate governance practices and processes enhance an organization's performance in emerging economies in particular and how this directly relates to the organization's value. This should also evaluate governance processes in various sectors such as financial services, healthcare, government, manufacturing, non-profit, educational institution among others. It would be particularly interesting to examine the impact of corporate governance in these sectors.

\section{ACKNOWLEDGMENTS}

My thanks to the experts who have contributed towards development of the template.

\section{REFERENCES}

1. Amit, R., \& Villalonga, B. (2006). Benefits and costs of control-enhancing mechanisms in U.S. family firms. SSRN Working Paper.

2. Arrigo, E. (2006). Code of Conduct and Corporate Governance. Management (www. unimib. it/symphonya), (1), 93-109. Retrieved April 29, 2016 from ftp://ftp.repec.org/opt/ReDIF/RePEc/sym/PDF/symjournl87.pdf

3. Arjoon S. (2005). Corporate governance. An ethical perspective. Journal of Business Ethics,61(4), 343-352. $\begin{array}{llll}\text { Retrieved } & \text { April } & 2016 & \text { from }\end{array}$ http://search.proquest.com.ezproxy.utica.edu/docview/198005400?OpenURIRefld=info:xri/sid:wcdiscovery\&acc ountid=28902

4. Bader, G. (2013, February 28). Separating the positions of CEO and Chairman: The debate rages on. In The Securities Edge. Retrieved April 24, 2016 from http://www.thesecuritiesedge.com/2013/02/separating-thepositions-of-ceo-and-chairman-the-debate-rages-on/

5. Dallas, G. (2011, August 24). Corporate governance in emerging markets. Harvard Law School Forum on Corporate Governance and Financial Regulation. Retrieved April 27, 2016 from https://corpgov.law.harvard.edu/2011/08/24/corporate-governance-in-emerging-markets/

6. Edwards, F. R. (2003). U.S. corporate governance: What went wrong and can it be fixed? Columbia University Business School. $\quad$ Retrieved $\quad$ April $29, \quad 2016$ from https://www0.gsb.columbia.edu/mygsb/faculty/research/pubfiles/1661/U.S.\%20Corporate\%20Governance\%201 0-05.pdf

7. Feleagă, N., Feleagă, L., Dragomir, V. D., \& Bigioi, A. D. (2011). Corporate Governance in emerging economies: The case of Romania. Theoretical and Applied Economics, 9(9), 5. Retrieved April 27, 2016 from http://www.store.ectap.ro/articole/632.pdf

8. Ferrarini, G. and Giudici, P. (2005). Financial Scandals and the Role of Private Enforcement: The Parmalat Case. European Corporate Governance Institute. Retrieved April, $20 \quad 2016$ from http://web.efzg.hr/dok/pra/hhorak/Financial\%20scandals\%20and\%20the\%20Role\%20of\%20Private\%20Enforce ment.pdf

9. Have Governance Reforms Spurred on by Parmalat's Collapse Given Investors a False Sense of Security? "Three years after the Parmalat scandal, what Italy still lacks is an open market for corporate control and a managerial culture sensitive to the value of corporate governance," says a Conference Board expert in a new study of international convergence of governance standards. (2006). PR Newswire, N/a. Retrieved April 20, 2016 http://www.lexisnexis.com.ezproxy.utica.edu/hottopics/Inacademic/?verb=sr\&csi=8054\&sr=HLEAD(Have+Gover nance+Reforms+Spurred+on+by+Parmalat\%27s+Collapse+Given+Investors+a+False+Sense+of+Security\%3F) + AND+DATE+IS+november+14+2006 
nternational Journal of Management and Information Technology

10. How Parmalat went sour. (2004, January 11) in Bloomberg News. Retrieved April 24, 2016 from http://www.bloomberg.com/news/articles/2004-01-11/how-parmalat-went-sour

11. Irungu, G. (2016, April 8). How Chase Bank director lent himself Ksh. 7.9 billion. The Business Daily. Retrieved April 27, 2016 from http://www.businessdailyafrica.com/Chase-Bank-director-borrowed-Sh7-9bn-withoutsecurity/-/539552/3150510/-/3apixnz/-/index.html

12. Jones, M. (2011). Creative Accounting, Fraud and International Accounting Scandals. Chichester, West Sussex, England: Wiley.

13. Klapper, L.F., and Love, I., Corporate Governance, Investor Protection, and Performance in Emerging Markets". Journal of Corporate Finance. 10, 2004, pp. 287-322

14. Melis, A. (2005), Corporate Governance Failures: to what extent is Parmalat a particularly Italian Case? Corporate Governance: An International Review, 13: 478-488. Retrieved April 23, 2016 from http://users.metropolia.fi/ minnak/ipw/Monika\%20KovarovaSimecek/To\%20what\%20extent\%20is\%20Parmalat\%20a\%20particulary\%20ltalian\%20case.pdf

15. New detention in Parmalat probe. (2004, February 25) in BBC News. Retrieved April 21, 2016 from http://news.bbc.co.uk/2/hi/business/3487192.stm

16. O'Shea, N. (2005). Governance how we've got where we are and what's next. Accountancy Ireland, 37(6), 33-37. Retrieved from http://search.proquest.com/docview/223171416?accountid=28902

17. Organization for Economic Cooperation and Development. (2015). G20/OECD Principles of corporate governance. G20/OECD Summit in Turkey. Retrieved from http://www.oecd.org/daf/ca/Corporate-GovernancePrinciples-ENG.pdf

18. Parmalat Securities Litigation (United States District Court Southern District of New York 2003).

19. Scott, R. and Davis, G. (2007). Organizations and Organizing. Rational, Natural, and Open System Perspectives. Pearson Prentice Hall.

20. Segato, L. (2006). A comparative analysis of shareholder protections in Italy and the United States: Parmalat as a case study. Northwestern Journal of International Law \& Business, 26(2), winter, 373-446. Retrieved April 25, 2016, from http://scholarlycommons.law.northwestern.edu/cgi/viewcontent.cgi?article=1627\&context=njillb

21. Sverige, C. (2004, January 6). The Parmalat scandal: Europe's ten-billion euro black hole. International Committee of the Fourth International (ICFI). Retrieved April 29, 2016 from https://www.wsws.org/en/articles/2004/01/parm-j06.html

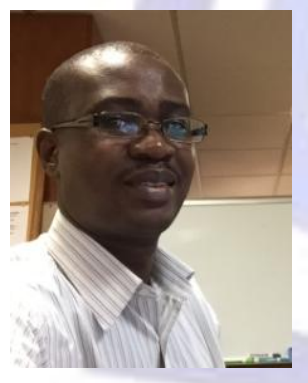

\section{Author' biography with Photo}

Mr. Emmanuel Ogutu works as a Financial Analyst with an Non-Governmental Organization based in Phoenix, Arizona, USA. He has recently graduated with an MBA in Economic Crime and Fraud Management from Utica College in Utica, New York, USA. He has over 15 years of combined experience in financial analysis, accounting, auditing, risk management, and compliance in international development, manufacturing, government and microfinance, mostly gained overseas. $\mathrm{He}$ is also a Certified Internal Audior (CIA) as well as a Certified Fraud Examiner (CFE). His experience in auditing has enabled him help his past employers design, develop and implement systems and controls that enhance governance and promore integrity in the work place. 